\title{
UMUR SIMPAN SAOS TOMAT PADA BERBAGAI KONSENTRASI BAHAN PENGENTAL
}

\author{
Catur Budi Handayani, A. Intan Niken Tari, dan Afriyanti \\ Prodi Teknologi Hasil Pertanian, Fakultas Pertanian Universitas Veteran Bangun Nusantara, \\ Jl. Letjen Sujono Humardani No. 1 Sukoharjo 57521. Telp. +62-0271-593156, fax. +62-0271-590165 Email : \\ caturjazuli@yahoo.com
}

\begin{abstract}
Abstrak
Penelitian tentang umur simpan saos tomat pada berbagai konsentrasi bahan pengental ini menggunakan tomat lokal dari daerah Sukoharjo dengan bahan pengental tepung maezena konsentrasi 5, 7.5 dan $10 \%$ dari buah tomat yang digunakan. Perhitungan umur simpan menggunakan metode Archenius dengan penyimpanan selama 4 minggu pada 3 suhu yang berbeda yaitu suhu refrigerator $\left(4^{\circ} \mathrm{C}\right)$, suhu kamar $\left(27^{\circ} \mathrm{C}\right)$, dan suhu $50^{\circ} \mathrm{C}$. Perhitungan didasarkan pada perubahan kadar air, pertumbuhan jamur dan uji organoleptik terhadap rasa. Hasil perhitungan menunjukkan bahwa umur simpan saos tomat terpendek adalah 24 hari untuk saos dengan bahan pengental 5 dan $7.5 \%$ dan 47 hari untuk untuk saos dengan bahan pengental $10 \%$, yang dihitung berdasarkan uji organoleptik terhadap rasa.
\end{abstract}

Kata kunci : saos tomat, umur simpan, bahan pengental

Abstract

Research on the shelf life of tomato sauce at various coagulant concentrations uses local tomatoes from the Sukoharjo with a concentration of 5, 7.5 and $10 \%$ of maezena flour from tomatoes used. The shelf life calculation uses the Archenius method with storage for 4 weeks at 3 different temperatures namely refrigerator temperature $\left(4^{\circ} \mathrm{C}\right)$, room temperature $\left(27^{\circ} \mathrm{C}\right)$, and temperature of $50{ }^{\circ} \mathrm{C}$. Calculations are based on changes in water content, fungal growth and organoleptic tests of taste. The calculation results show that the shortest shelf life of tomato sauce is 24 days for sauces with 5 and $7.5 \%$ coagulant and 47 days for sauces with $10 \%$ coagulant, which are calculated based on organoleptic test of taste.

Keywords: tomato sauce, shelf life, coagulant

\section{PENDAHULUAN}

\subsection{Tomat dan Saos Tomat}

Tomat (Licopersicum esculentum Mill.) merupakan salah satu produk hortikultura yang berlimpah di pasar. Lahan tomat di Jawa Tengah pada tahun 2015 mencapai 4.371 ha dengan produksi mencapai 62. 928 ton. Produksi tomat tertinggi di Indonesia adalah provinsi Jawa Barat dengan luas areal panen mencapai 10.100 dengan jumlah produksi 298.445 ton (BPS dan Kementerian Pertanian $\mathrm{RI})$.

Tomat merupakan salah satu jenis sayuran buah yang dibutuhkan pada saat ini, baik dalam bentuk segar maupun olahan (industri). Sebagai buah segar, tomat merupakan sumber vitamin $A$ dan $C$ disamping mengandung sejumlah mineral yang dibutuhkan tubuh seperti Kalium, Fosfat dan Calsium.
Tomat mengandung zat likopen yang memberikan warna merah pada tomat. Likopen merupakan karotenoid yang bersifat antioksidan yang telah diketahui memiliki kemampuan mencegah kanker prostat, payudara, rahim dan menyusutkan tumor (Clinton et al 1996 dalam Muctadi.2012)

Kandungan vitamin $\mathrm{C}$ dalam buah tomat relative cukup banyak sehingga dipercaya mempercepat kesembuhan luka, mencegah terjangkitnya penyakit skorbut, menghindarkan perdarahan dan pembuluh darah halus, dan membuat kulit bebas dari jerawat. Kandungan vitamin A pada tomat juga cukup tinggi bisa membantu penyembuhan buta malam.

Tomat juga digunakan sebagai sayuran dalam masakan, bumbu masak, bahan baku industri pangan maupun obat-obatan dan kosmetik. Karena masa panen buah tomat hanya 2 kali setahun, maka walaupun 
produksinya melimpah kadang suatu saat tidak banyak ada di pasar. Kelangkaan ini juga disebabkan karena buah tomah tidak tahan lama disimpan. Pada suhu ruang buah tomat hanya bertahan selama $3-4$ hari, sedangkan pada suhu refrigerator buah tomat bisa bertahan $1-2$ minggu saja. Pada saat musim panen sering kali terjadi ketimpangan antara jumlah yang tersedia dan permintaaan di pasar sehingga banyak buah tomat yang tidak termanfaatkan atau terjual dengan harga yang sangat murah.

Pengolahan buah tomat selama ini belum banyak variasi. Pemanfaatan buah tomat yang banyak dilakukan adalah dengan mengolahnya menjadi saos tomat. Produk inipun hanya mampu bertahan selama kurang lebih 2 tahun dengan cara pengolahan yang baik seperti pada industri besar. Pengolahan saos tomat untuk industri rumah tangga perlu digalakkan untuk memanfaatkan buah tomat yang melimpah terutama pada musim panen. Pengolahan yang baik diikuti dengan pengemasan yang benar akan menghasilkan saos tomat yang baik dan umur simpan yang panjang. Salah satu unsur yang berpengaruh pada umur simpan adalah kadar air bahan pangan tersebut.

Tomat sangat rentan terhadap serangan yeast dan jamur, begitu pula hasil olahannya. Pengolahan tomat menjadi saos melibatkan perlakuan pemanasan dan penambahan bahan lain (bumbu-bumbu dan pengental) sehinggga memungkinkan terjadinya pencegahan dan penghambatan pertumbuhan jamur pada bahan tersebut. Bumbu-bumbu terdiri dari campuran beberapa rempahrempah yang dapat menghambat pertumbuhan jamur, sedangkan bahan pengental dapat berfungsi mengurangi kadar air dalam saos tomat. Belum diketahui berapa konsentrasi bahan pengental yang optimal agar saos tomat dapat diterima dengan baik oleh konsumen sesuai standard SNI dan mempunyai umur simpan yang panjang sehingga penelitian ini perlu dilakukan.

\subsection{Pendugaan Umur Simpan dengan Metode ASLT}

Umur simpan produk pangan adalah selang waktu antara saat produksi hingga konsumsi dimana produk dalam kondisi yang memuaskan berdasarkan karakteritik penampakan, rasa, aroma, tekstur dan nilai gizi (Institute of Food Science and Technology, 1974). Kendala yang dihadapi oleh industri pangan dalam menentukan umur simpan suatu produk pangan adalah waktu, oleh karenanya diperlukan suatu metode pendugaan umur simpan yang cepat, mudah, murah dan mendekati umur simpan yang sebenarnya. Salah satu metode pendugaan umur simpan yang dapat diterapkan adalah metode Accelerated Shelf-Life Testing (ASLT) yaitu dengan cara menyimpan produk pada lingkungan yang menyebabkan mudah rusak, baik pada suhu atau kelembaban ruang yang lebih singkat dengan akurasi yang baik.

Untuk pendugaan umur simpan produk pangan yang mudah rusak oleh reaksi kimia, seterti oksidasi lemak, reaksi Mailard, denaturasi protein dan sebagainya metode ASLT model Arrhenius banyak digunakan. Karena reaksi kimia dipengaruhi oleh suhu, maka model Arrhenius menstimulasi percepatan kerusakan produk pada kondisi penyimpanan suhu tinggi di atas suhu penyimpanan normal. Tipe kerusakan yang ini antara lain degradasi enzimatis, reaksi kecoklatan non enzimatis, reaksi oksidasi lemak, ketengikan, pertumbuhan mikrobia dan produksi off flavor oleh mikrobia.

Model Arrhenius dilakukan dengan menyimpan produk pangan dengan kemasan akhir pada minimal tiga suhu penyimpanan ekstrim. Percobaan dengan metode ini bertujuan untuk menentukan konstanta laju reaksi (k) pada beberapa suhu penyimpanan ekstrim, kemudian dilakukan ekstrapolasi untuk menghitung konstanta laju reaksi (k) pada suhu penyimpanan yang diinginkan dengan menggunakan persamaan Arrhenius. Dari persamaan tersebut dapat ditentukan nilai k pada suhu penyimpanan umur simpan, kemudian digunakan perhitungan umur 
simpan sesuai dengan ordo reaksinya (Kusnandar, 2010 dan Pranoto dkk, 2012). Metode ini telah banyak diterapkan untuk menduga umur simpan selain saos tomat diantaranya : Keripik Tempe Sagu dalam Pengemas Aluminiun Foil (Afrianti dkk. 2018), Keripik Tempe Sagu dalam Pengemas Plastik (Afrianti dkk. 2017), Kacang Rendah Lemak (Pranoto, dkk. 2012).

\section{METODE PENELITIAN}

\subsection{Pembuatan Saos Tomat}

Saos tomat ini dibuat menggunakan tomat lokal, bumbu-bumbu dan bahan pengental (maezena) yang dibeli di pasar Sukoharjo. Pembuatan saos tomat dilakukan seperti pada Gambar 1. Buah tomat dicuci bersih, kemudian dimasukkan dalam air mendidih selama 5 menit. Kemudian buah tomat dihancurkan dengan blender dan disaring. Bubur buah dimasak dengan api kecil dan ditambahkan bumbu-bumbu yang telah dimasukkan dalam kantong berlubang. Setelah mendidih bahan pengental (tepung maizena) dimasukkan. Pemasakan dilakukan selama kurang lebih 15 menit. Pengemasan dilakukan dalam toples yang terlebih dahulu disterilkan dengan pengukusan dan dilakukan penyegelan.

\subsection{Variasi Perlakuan}

Perlakuan pada penelitian ini adalah variasi jumlah bahan pengental (tepung maizena) yaitu $5,7.5$ dan $10 \%$ dari buah tomat yang digunakan. Untuk menentukan umur simpan saos tomat yang dibuat akan disimpan pada 3 macam suhu yang berbeda yaitu suhu refrigerator $\left(4^{\circ} \mathrm{C}\right)$, suhu ruang $\left(27^{\circ} \mathrm{C}\right)$, dan suhu $50{ }^{\circ} \mathrm{C}$.

\subsection{Analisa yang dilakukan}

a. Pengukuran kadar air saos dengan metode penguapan seminggu sekali selama 4 minggu

b. Perhitungan jumlah jamur dengan plate count jamur menggunakan medium Potato Dextrosa Agar seminggu sekali selama 4 minggu

c. Uji organoleptik meliputi terhadap rasa dilakukan seminggu sekali selama 4 minggu

\subsection{Rancangan Percobaan}

Rancangan percobaan yang digunakan adalah Rancangan Acak Lengkap (RAL) dengan perlakuan variasi bahan pengental.

\subsection{Analisa Data}

Data yang dihasilkan digunakan untuk menghitung umur simpan saos dengan metode Arrchenius

\section{HASIL DAN PEMBAHASAN}

\subsection{Perhitungan Umur Simpan} berdasarkan Kadar Air

Kadar air saos tomat selama penyimpanan disajikan pada Tabel 3.

Dengan menggunakan metode Arrchenius, perhitungan umur simpan saos tomat berdasarkan pengukuran kadar air pada saos tomat dengan bahan pengental $5 \%$ terlihat pada Gambar 2. Dari Gambar 2 selanjutnya dibuat persamaan regresi hubungan antara $1 / T$ dan In $k$ seperti pada Gambar 3. Selanjutnya berdasarkan Gambar 3 tersebut dihitung umur simpannya. Dengan metode yang sama umur simpan saos tomat dengan kadar bahan pengental yang berbeda disajikan pada Tabel 4. 


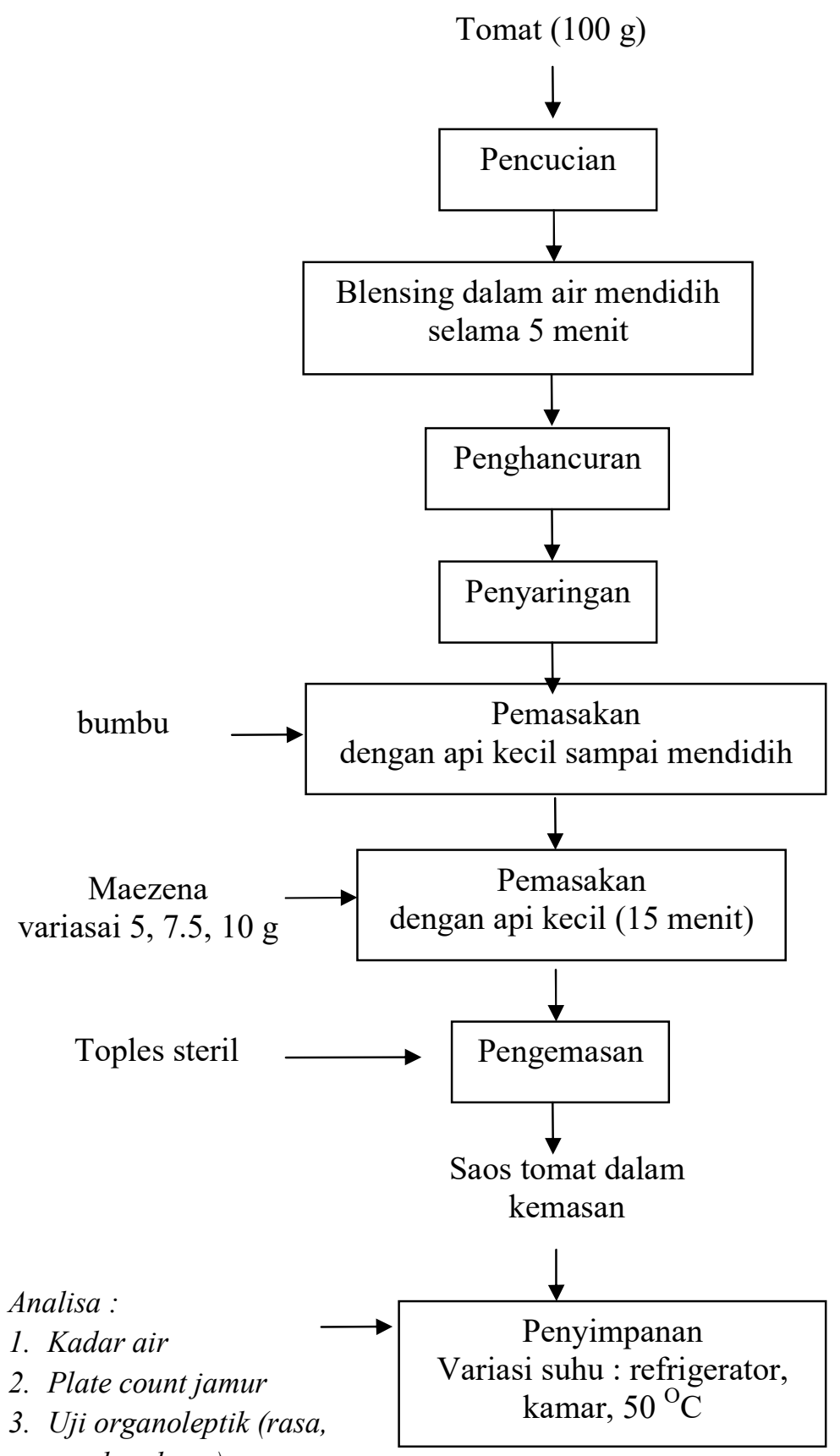

warna, kesukaan)

Gambar 1. Bagan jalannya penelitian 
Tabel 3. Kadar Air Saos Tomat (\%) selama Penyimpanan

\begin{tabular}{ccccccc}
\hline Bahan & Suhu & Hari ke & Hari ke & Hari ke & Hari ke & Hari ke \\
Pengental & Penyimpanan & 0 & 7 & 14 & 21 & 28 \\
\hline $5 \%$ & ref & 91,8 & 91,7 & 91,7 & 92,9 & 92,2 \\
& ruang & 91,9 & 91,7 & 91,9 & 92,7 & 92,2 \\
& $50^{\circ} \mathrm{C}$ & 97,3 & 91,8 & 91,8 & 92,0 & 91,1 \\
$7.5 \%$ & ref & 91,5 & 91,2 & 91,4 & 92,7 & 91,9 \\
& ruang & 91,5 & 91,1 & 91,5 & 92,4 & 91,1 \\
& $50^{\circ} \mathrm{C}$ & 91,5 & 91,6 & 91,5 & 92,1 & 91,9 \\
$10 \%$ & ref & 91,2 & 90,3 & 91,1 & 91,1 & 91,2 \\
& ruang & 91,1 & 90,4 & 90,2 & 90,2 & 90,2 \\
& $50^{\circ} \mathrm{C}$ & 90,9 & 90,5 & 90,5 & 90,4 & 90,3 \\
\hline
\end{tabular}

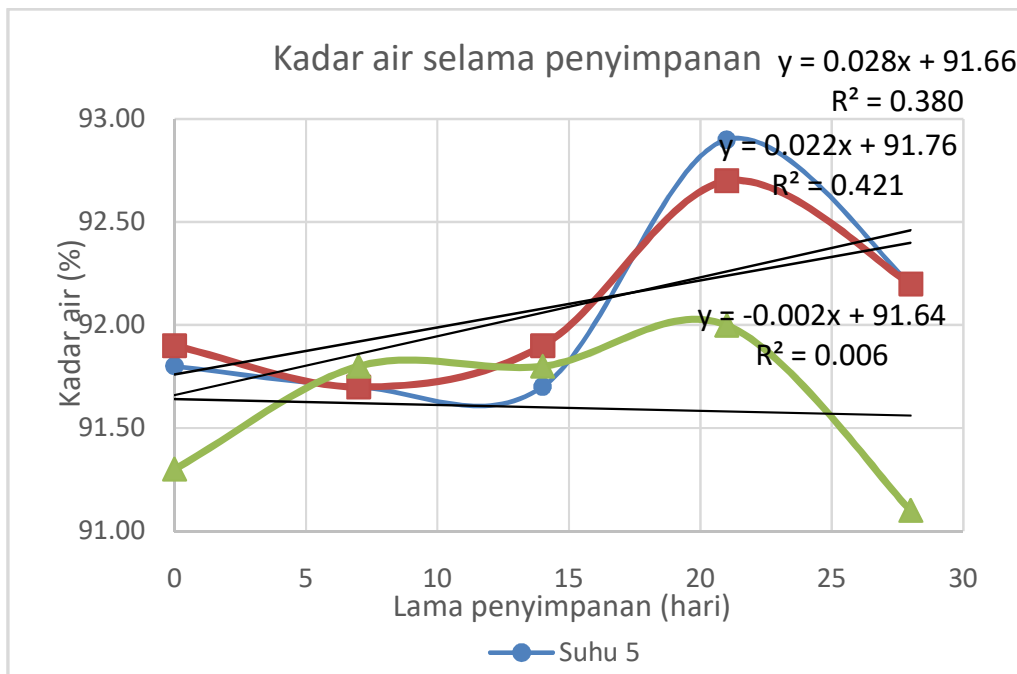

Gambar 2. Grafik perubahan kadar air pada saos tomat dengan bahan pengental $5 \%$ selama penyimpanan

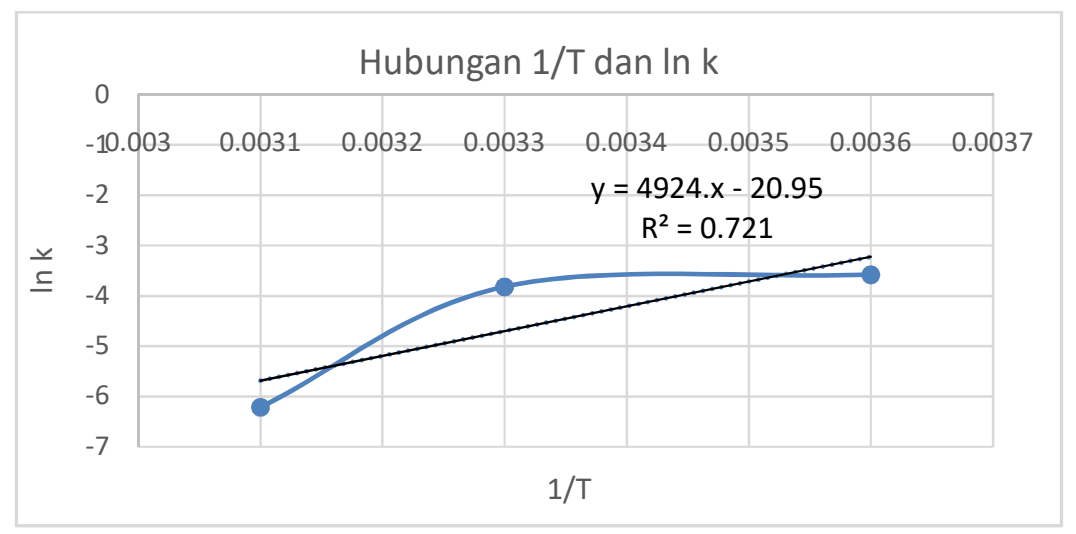

Gambar 3. Grafik hubungan 1/T dan In k pada perubahan kadar air saos tomat dengan bahan pengental $5 \%$ selama penyimpanan 
Tabel 4. Umur simpan Saos Tomat berdasarkan Kadar Air

\begin{tabular}{cc}
\hline Bahan Pengental & Umur Simpan (hari) \\
\hline $5 \%$ & 44 \\
$7.5 \%$ & 33 \\
$10 \%$ & 76
\end{tabular}

Tabel 5. Jumlah Jamur Saos Tomat Selama Penyimpanan

\begin{tabular}{ccccccc}
\hline Bahan & Suhu & Hari ke & Hari ke & Hari ke & Hari ke & Hari ke \\
Pengental & Penyimpanan & 0 & 7 & 14 & 21 & 28 \\
\hline $5 \%$ & ref & $75 \times 10^{3}$ & $36 \times 10^{4}$ & $56 \times 10^{4}$ & $33 \times 10^{4}$ & $65 \times 10^{4}$ \\
& ruang & $75 \times 10^{3}$ & $66 \times 10^{4}$ & $86 \times 10^{4}$ & $76 \times 10^{4}$ & $97 \times 10^{4}$ \\
& $50^{\circ} \mathrm{C}$ & $75 \times 10^{3}$ & $37 \times 10^{5}$ & $47 \times 10^{5}$ & $39 \times 10^{5}$ & $37 \times 10^{5}$ \\
$7.5 \%$ & ref & $91 \times 10^{3}$ & $32 \times 10^{4}$ & $52 \times 10^{4}$ & $31 \times 10^{4}$ & $65 \times 10^{4}$ \\
& ruang & $91 \times 10^{3}$ & $87 \times 10^{4}$ & $97 \times 10^{4}$ & $91 \times 10^{4}$ & $68 \times 10^{4}$ \\
& $50^{\circ} \mathrm{C}$ & $91 \times 10^{3}$ & $33 \times 10^{5}$ & $53 \times 10^{5}$ & $69 \times 10^{5}$ & $55 \times 10^{5}$ \\
$10 \%$ & ref & $67 \times 10^{3}$ & $33 \times 10^{4}$ & $53 \times 10^{4}$ & $33 \times 10^{4}$ & $51 \times 10^{4}$ \\
& ruang & $67 \times 10^{3}$ & $74 \times 10^{4}$ & $94 \times 10^{4}$ & $76 \times 10^{4}$ & $82 \times 10^{4}$ \\
& $50^{\circ} \mathrm{C}$ & $67 \times 10^{3}$ & $39 \times 10^{5}$ & $59 \times 10^{5}$ & $81 \times 10^{5}$ & $66 \times 10^{5}$ \\
\hline
\end{tabular}

\subsection{Perhitungan Umur Simpan berdasarkan Pertumbuhan Jamur}

Pertumbuhan jamur selama penyimpanan dilihat dengan menghitung jumlah jamur menggunakan metode plate count jamur dengan medium Potato Dextrosa Agar (PDA). Hasil perhitungan jamur dapat dilihat pada Tabel 5.

Dengan menggunakan metode Arrchenius, perhitungan umur simpan saos tomat berdasarkan pertumbuhan jamur pada saos tomat dengan bahan pengental $5 \%$ terlihat pada Gambar 4. Dari Gambar 4 selanjutnya dibuat persamaan regresi hubungan antara 1/T dan In k seperti pada Gambar 5. Selanjutnya berdasarkan Gambar 5 tersebut dihitung umur simpannya. Dengan metode yang sama umur simpan saos tomat dengan kadar bahan pengental yang berbeda disajikan pada Tabel 6.

\subsection{Perhitungan Umur Simpan berdasarkan Uji Organoleptik Rasa}

Uji organoleptik terhadap saos tomat yang dibuat dilakukan menggunakan 10 panelis tidak terlatih berdasarkan skor kesukaan. Rata-rata hasil uji organoleptik terhadap rasa disajikan pada Tabel 7.

Dengan menggunakan metode Arrchenius, perhitungan umur simpan saos tomat berdasarkan uji organoleptik terhadap rasa pada saos tomat dengan bahan pengental $5 \%$ terlihat pada Gambar 6. Dari Gambar 6 selanjutnya dibuat persamaan regresi hubungan antara $1 / T$ dan In $k$ seperti pada Gambar 7. Selanjutnya berdasarkan Gambar 7 tersebut dihitung umur simpannya.Dengan metode yang sama umur simpan saos tomat dengan kadar bahan pengental yang berbeda disajikan pada Tabel 8 . 


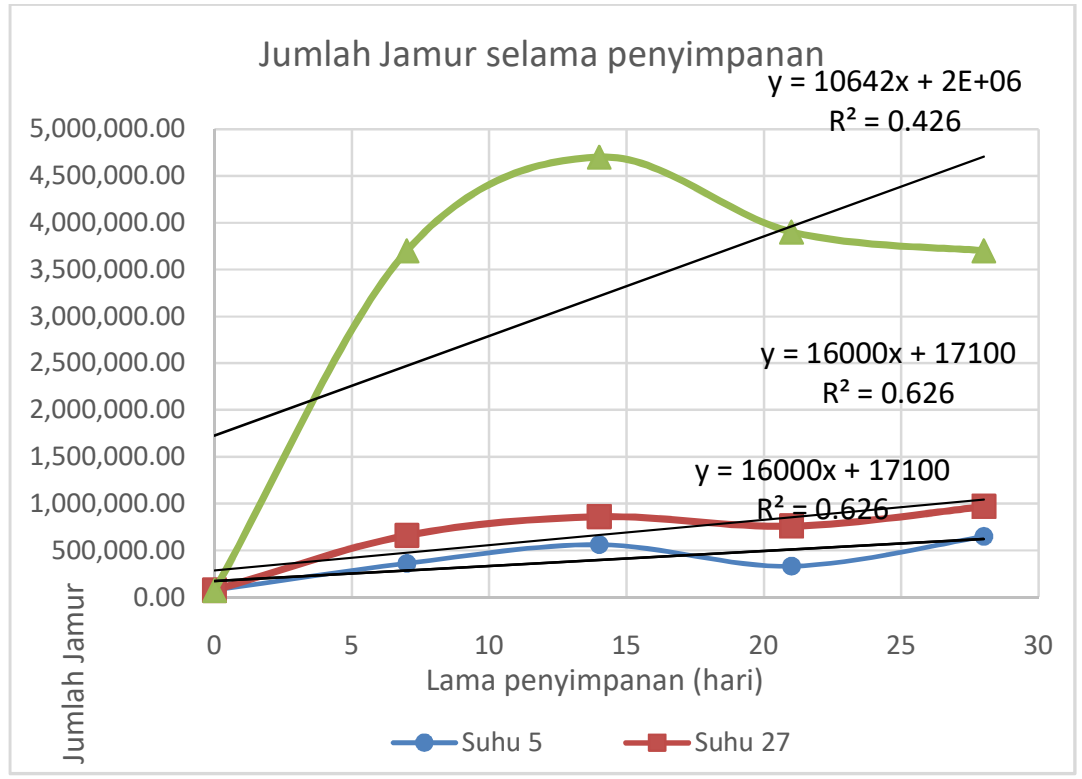

Gambar 4. Grafik perubahan pertumbuhan jamur pada saos tomat dengan bahan pengental $5 \%$ selama penyimpanan

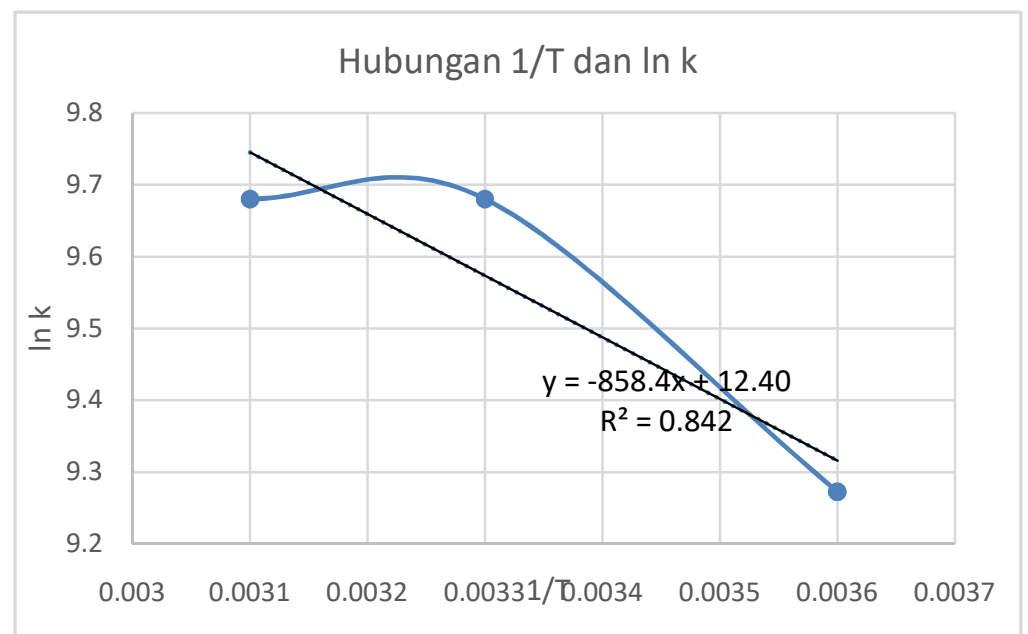

Gambar 5. Grafik hubungan 1/T dan In k pada perubahan pertumbuhan jamur pada saos tomat dengan bahan pengental $5 \%$ selama penyimpanan

Tabel 6. Umur simpan Saos Tomat berdasarkan Pertumbuhan Jamur

\begin{tabular}{cc}
\hline Bahan Pengental & Umur Simpan (hari) \\
\hline $5 \%$ & 59 \\
$7.5 \%$ & 33 \\
$10 \%$ & 47 \\
\hline
\end{tabular}


Tabel 7. Rata-rata hasil Uji Organoleptik terhadap Rasa

\begin{tabular}{ccccccc}
\hline Bahan & Suhu & Hari ke & Hari ke & Hari ke & Hari ke & Hari ke \\
Pengental & Penyimpanan & 0 & 7 & 14 & 21 & 28 \\
\hline $5 \%$ & ref & 2,8 & 2,9 & 2,8 & 2,4 & 2,4 \\
& ruang & 2,8 & 2,4 & 2 & 2 & 2 \\
& $50^{\circ} \mathrm{C}$ & 3 & 1 & 1 & 1 & 1 \\
$7.5 \%$ & ref & 2,8 & 2,9 & 2,9 & 2,4 & 2,2 \\
& ruang & 2,8 & 2,6 & 2 & 2 & 2 \\
& $50^{\circ} \mathrm{C}$ & 3 & 1 & 1 & 1 & 1 \\
$10 \%$ & ref & 2,8 & 3 & 3 & 3 & 3 \\
& ruang & 2,8 & 2,4 & 2,2 & 2,2 & 2,2 \\
& $50^{\circ} \mathrm{C}$ & 3 & 1 & 1 & 1 & 1 \\
\hline
\end{tabular}

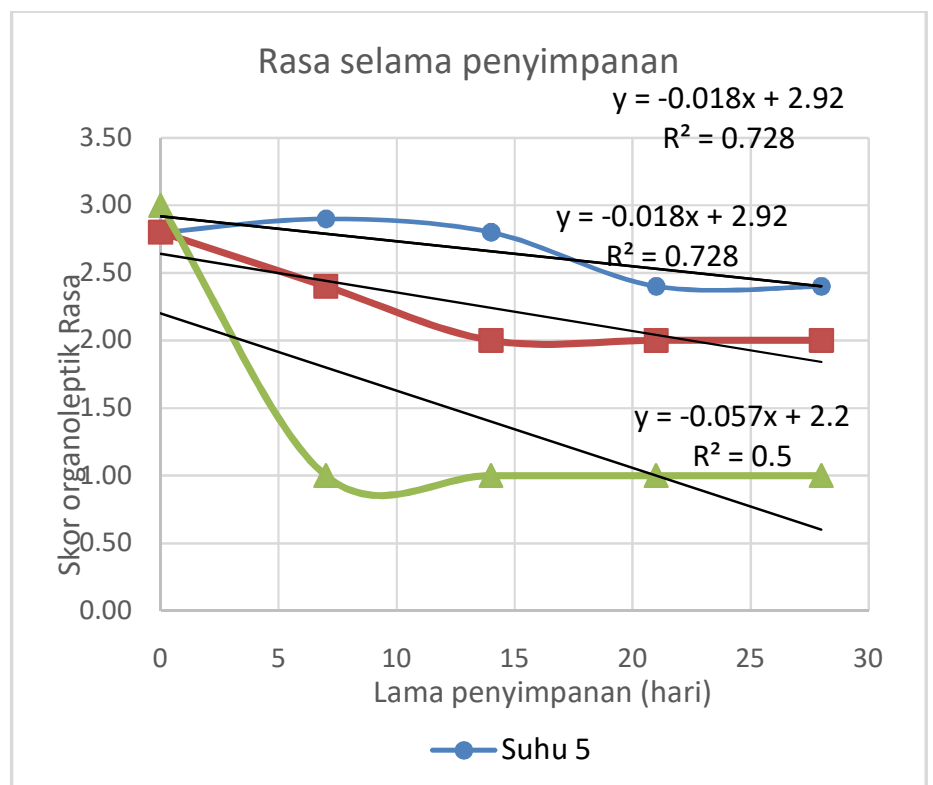

Gambar 6. Grafik perubahan skor organoleptik terhadap rasa pada saos tomat dengan bahan pengental $5 \%$ selama penyimpanan

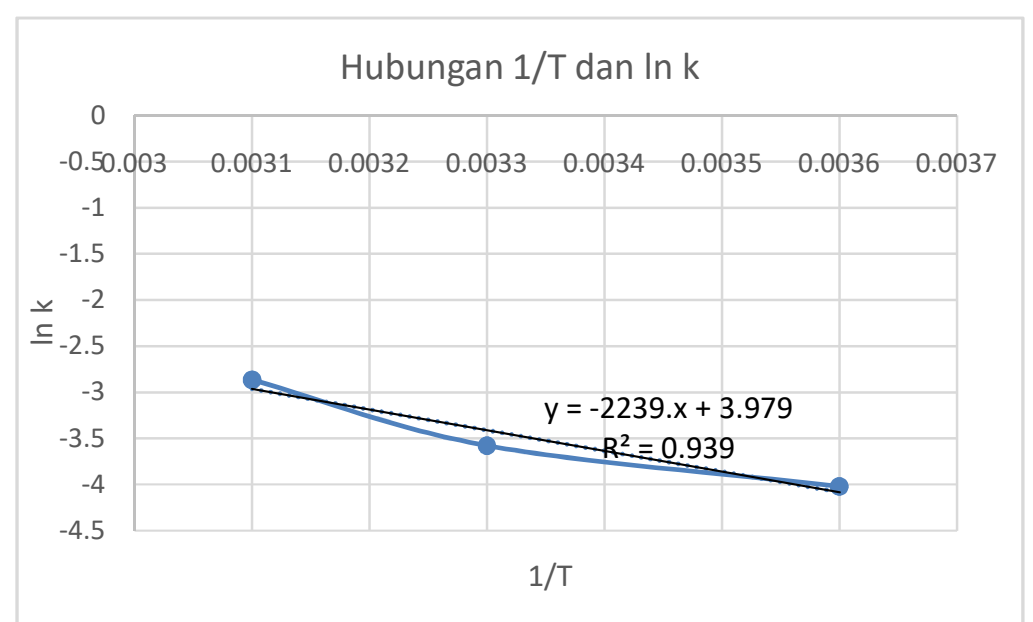

Gambar 7. Grafik hubungan 1/T dan In k pada perubahan skor organoleptik terhadap rasa pada saos tomat dengan bahan pengental $5 \%$ selama penyimpanan 
Tabel 8. Umur simpan Saos Tomat berdasarkan Uji Organoleptik terhadap Rasa

\begin{tabular}{cc}
\hline Bahan Pengental & Umur Simpan (hari) \\
\hline $5 \%$ & 24 \\
$7.5 \%$ & 24 \\
$10 \%$ & 47 \\
\hline
\end{tabular}

\subsection{Perhitungan Umur Simpan berdasarkan Umur Simpan Terpendek}

Dari perhitungan-perhitungan umur simpan berdasarkan berbagai hal tersebut didapatkan hasil bahwa umur simpan saos tomat terpendek adalah seperti terlihat pada Tabel 13 yang merupakan kesimpulan dari hasil-hasil perhitungan umur simpan saos tomat yang dibuat. Menurut perhitungan Meikapasa (2016) yang menghitung umur simpan saos tomat berdasarkan kadar air disimpulkan bahwa umur simpan saos tomat dalam suhu ruang adalah 74 hari dan berdasarkan pertumbuhan jamur 25 hari. Pada penelitian ini umur simpan saos tomat berdasarkan perubahan kadar air sekitar 40 hari dan berdasarkan pertumbuhan jamur sekitar 33 hari. Hasil ini berbeda dengan penelitian ini diduga kerena pengaruh penggunaan bahan pengental. Dari perhitungan-perhitungan tersebut, umur simpan terpendek ternyata didapatkan pada perhitungan berdasarkan uji organoleptik terhadap warna. Hal ini dapat dimengerti karena pembuatan saos tomat peda penelitian ini tidak menambahkan bahan pewarna, sehingga warna yang dihasilkan pucat dan makin pucat selama penyimpanan.

Tabel 13. Umur simpan Saos Tomat Terpendek

\begin{tabular}{cc}
\hline Bahan Pengental & Umur Simpan (hari) \\
\hline $5 \%$ & 24 \\
$7.5 \%$ & 24 \\
$10 \%$ & 47 \\
\hline
\end{tabular}

\section{KESIMPULAN}

Dari penelitian yang telah dilakukan dapat diambil kesimpulan bahwa umur simpan saos tomat dengan variasi bahan pengental memperlihatkan hasil yang berbeda-beda karena perbedaan dasar pengamatan yang dipakai. Umur simpan terpendek didapatkan dari perhitungan berdasarkan uji organoleptik terhadap rasa yaitu 24 hari untuk saos tomat yang dibuat dengan bahan pengental 5 dan 7,5 $\%$ dan 47 hari untuk saos tomat yang dibuat dengan bahan pengental $10 \%$.

\section{DAFTAR PUSTAKA}

Afriyanti. 2017. Pendugaan Umur Simpan Keripik Tempe Sagu Menggunakan Pengemas Plastik PP dengan Metode Arrchenius . Jurnal IImu Pangan dan
Hasil Pertanian. Vol 1, No. 1 Tahun 2017.

Afriyanti., Catur Budi Handayani., A.Intan Niken Tari. 2018. Pendugaan Umur Simpan Keripik Tempe Sagu dalam Pengemas Aluminium Foil . Jurnal Agrisaintifika. Vol 2, No. 1 Tahun 2018.

Anonim. 2013. Peningkatan Kualitas dan Daya Simpan Saus Tomat Dengan Blasing. http://sulsel.litbang.pertanian.go.id/ind/in dex.php?option=com_content\&view=cat egory\&id=164\&Itemid=342

Dewayani, D dan Darmawidah, A. 2013. Peningkatan Kualitas dan Daya Simpan Saus Tomat Dengan Blasing. http://sulsel.litbang.pertanian.go.id/ind/in dex.php?option=com content\&view=arti cle\&id=842: peningkatan-kualitas-dandaya-simpan-saus-tomat-dengan- 
blasing\&catid=164:buletin-nomor-6tahun-2012\&ltemid=342

Endrah W . 2009. Aspek mutu pengolahan saus tomat Aspek Mutu Pengolahan Saus Tomat. http://endrah.blogspot.co.id/2009/10/asp ek-mutu-pengolahan-saus-tomat.html. 19 Jan 2017

Kusnandar dan Fei. 2010. Pendugaan Umur Simpan Metode ASLT. http://itp.fateta.ipb.ac.id/id/index.php?opt ion=com content\&task=view\&id=86\&lte $\underline{\mathrm{mid}=94.19}$ Januari 2017-01-20

Kartiko, B. Uji Inderawi, PAU Pangan dan Gizi UGM, Yogyakarta
Meikapasa, N.W.P. 2016. Penurunan Mutu Dan Pendugaan Umur Simpan Saus Tomat

Pada Suhu Berbeda. Media Bina IImiah 45, Volume 10, No. 12, Desember 2016. ISSN No. 1978-3787. http://www.Ipsdimataram.com

Muchtadi.D. 2012. Pangan Fungsional dan Senyawa Bioaktif. Alfabeta,CV. Bandung

Pranoto, Y., Marseno, D.W., Haryadi. 2012. Perkiraan Umur Simpan Kacang Rendah Lemak Dilapisi Dengan Carboxymethyl Cellulose Menggunakan Metode Accelerated Shelf-Life Test (Aslt). Agritech, Vol. 32, No. 3, Agustus 2012 